\title{
Socio-Economic Contribution of Shea Tree (Vitellaria paradoxa) in Support of Rural Livelihood in Ganye, Sourtheastern Adamawa State, Nigeria
}

\author{
Jamala, G. Y ${ }^{1^{*}}$, M.Y. Jada ${ }^{2}$, J. J. Yidau and L. Joel ${ }^{1}$ \\ ${ }^{1 *}$ Adamawa State College of Agriculture, Ganye, Nigeria \\ ${ }^{2}$ Modibbo Adama University of Technology, Yola, Nigeria
}

\begin{abstract}
Vitellaria paradoxa is an important economic tree that plays a vital role in support of rural livelihood in an area where its uses are well understood. This study was conducted to examine the socioeconomic contribution of Vitellaria paradoxa in support of rural livelihood in Ganye, Adamawa State, Nigeria. One hundred and fifty (150) respondents were randomly selected for the study. Majority (63\%) of the respondents engaged in Shea butter enterprise were women. The result indicted that about $76 \%$ of the respondents had no formal education, 53\% pointed out that their primary occupation is Shea butter processing even though they are also involved in other form of activities in order to diversify their economy. The result shows that $67 \%$ of the respondents often picked Shea fruits under trees which they use as input, 27\% maintained that they both picked and also buy more Shea nuts from pickers. The quantity of Shea nuts picked per day varied form 1/4 to 1 bag per day (77\%), 2-4 bags (17\%) and 5-8 bags (3\%) per day. Also majority (73\%) of the respondents use manual method for Shea butter processing, (23\%) mentioned that they use mechanized method of processing. All the respondents in the study area maintained that Shea trees play vital role in support of rural livelihood. $60 \%$ of the respondent's mentioned that the major challenges encountered are lack of processing equipment, technical skills, low inputs and capital. About $90 \%$ of the respondents mentioned that they do not use to get any assistant from government or non-governmental organization. When the respondents were asked on how these challenges could be addressed? About $90 \%$ of them maintain that government should provide the input, equipment and also provide modern training to enhance their local skill.
\end{abstract}

Keywords: Livelihood, Poverty, Shea nuts, Women, Economy, Rural

\section{Introduction}

According to Agbogidi (2010), households world over depends on natural resources in order to meet a large number of their basic necessities. The types of resources and utilization pattern vary with ecological zone and socio-cultural area. Agbogidi and Eshegbeyi (2008) maintained that forest provides a wide range of benefits at both the local, national and global levels. Vitelliria paradoxa C.F Gaertu. (Sapotacea) commonly called Shea tree is one of the trees mostly exploited by rural women in the Shea butter enterprise. The tree is a characteristic species in Sudano Sahelian Savanna in Africa. The different parts of the tree are usually employed in various field of the everyday life. The wood of Shea tree is used for making tools while the roots and bark have medicinal and pesticide applications. The sweet pulp of its fruits represents a valuable source of energy during the early part of the rainy season. The butter extracted from the kennels is the most important product of Shea tree. It is frequently used for local domestic purposes such as cooking, lightning, in soap manufacture or as skin moisturizer, as well as in traditional medicine (Hall et al., 1996). Economic interest of Shea tree had leads the scientists to be interested in the plant. The Shea nuts are important non-timber forest products that play major role in enhancing rural welfare and in supplying urban and industrial markets as well as in the inputs for rural economics (Adeokun et al., 2002). Agbogidi and Okonta (2003) pointed out that a large proportion of rural population earns their livelihood from the extraction and sales of Shea nuts products thereby improving the quality of life and standard of living of rural population.

The West African region is currently the dominant supplier of all the African nations that produce Shea nuts. Nigeria and Mali are the leading producers, followed by Burkina Faso and Ghana. There is an estimated 500 million productive Shea trees in the Sahel region, with production capacity of approximately 2.5 million M.T. The majority of Shea butter is constituted into several different products: cooking oil (mainly in Africa), candle making, cosmetics (soaps, moisturizer creams emulsion, and hair conditioners), pharmaceuticals (ointments anti inflammatory), and food (Supplement for cocoa butter, in pastries ice creams).

The Shea butter industry is mainly driven by the work of women across West African. Women collect the Shea nuts extract the butter and sell the refined product. It was estimate that the Shea tree provides more than half of a Women's incomes in the Sahel regions, and there are over two million Women working directly or indirectly with Shea trees. 
Women are the main drives behind the production of Shea butter and Shea tree is seen as sacred. Women's income in West Africa for most part is directly related to the production of Shea butter. Therefore any direct impact to the Shea tree, such as using it for charcoal production or fire wood, threatens one of the main income generators for women.

Men totally exclude themselves from the act due mainly to non-recognition of the Shea butter industry potential to help the economy and women have their own limitation of complex including lack of access to key factors of production, lack of appropriate funding, and high level of domestic work. Others are inadequate modern technologies, under-developed markets and lack of storage facilities. Reliance on low level of technology input is inadequate to lead to desired rapid and sustained increases in the contribution and utilization of Shea tree. Lack of substantive information on the economic values of Shea trees has undermined their contribution to the national gross domestic products (Agbogidi and Ofuoku, 2005). Agbogidi (2010) maintained that strengthening the local people's capacity to adopt sound and sustainable agro forestry practices such as retaining of economic trees on farmland can remarkably increase profit of rural farmers. On the other hand, availability of Shea trees could be enhanced through enrichment planting.

In a previous study conducted by Lovett (2004), he pointed out that stakeholder's involvement in the Shea butter processing business includes village pickers and post harvest processors of Shea nuts, local buying agents, rural or urban Butter processors. Types of Shea butter processing technologies in West Africa including Nigeria, Shea butter extraction processes is categories into three main methods. Traditional, semi mechanized and fully mechanized industrial systems (Addaquay, 2004).

Hall et al., (1996) estimated that the production of $1 \mathrm{~kg}$ of Shea butter takes one person 20-30 hours, from collection to final product. It is also estimated that $8.5-10.0 \mathrm{~kg}$ of fuel-wood is needed to produce $1 \mathrm{~kg}$ of Shea butter. Extraction rates are also low at about $25-60 \%$.

Attempts have been made to introduce new technologies in to the gathering, storage and processing of Shea butter (Wallace-Bruce, 1995). The semi-mechanized system of extraction utilizes appropriate technology to mechanize some of the unit operations of the manual traditional systems. According to addaquay (2004), such technological advancement has led to an increased in extraction rate from 20 percent to 35-40 percent (referred to as the semi-mechanized system). The semi-mechanized system could by very suitable for a developing country like Nigeria; as a result further research ought to be conducted to promote extensive use of the semi-mechanized system in Nigeria

Fully mechanized system of production in view of addaquay (2004), mechanized processing in West Africa yields $30-40 \%$ of Shea butter from raw nuts, but more efficient, fully mechanized system achieve extraction rates of between $42 \%$ and $80 \%$ this is relatively higher compared with $25 \%-60 \%$ of extraction rate of the traditional and semi-mechanized systems. Addaquay (2004) again state that, most of the Nigeria plants produce less than $25 \%$ of their installed capacity and operates only six months in a year or order to offset the high cost of storing Shea nuts throughout the year. A further research must however be carried out to find out economic approach for storing Shea nuts in Nigeria to enable processing plants function all year round. Besides studies into crude Shea butter storage possibilities cold reduce the higher cost of storing Shea nuts in Nigeria.

\section{Contribution of Shea Butter Industry to Development in Nigeria}

The Shea butter industry is a good source of socio-economic development for northern Nigeria and the entire nation as a whole. The main benefits of Shea butter to Nigeria include foreign exchange, food security, employment generation, poverty alleviation among others. According to techno serve (2004) about 3,000 household in Northern Nigeria are engage in the Shea industry, it is estimate that the average household size is 13 people and these household produce and market 4 million (USD) worth of Shea butter annually.

Hall et al. (1996) noted that the harvest season of Shea nuts coincides with the early wet season, and the edible fruit pulp forms a substantial addition to diet. About 70,000 MT of Shea butter is consumed in Nigeria annually (Lovett, 2004). However, the most important role played by Shea in northern Nigeria is the fact that Shea picked by farmers are mainly sold to raise funds for the purchase of food. As stated by kletter (2002), picking of Shea fruits coincides with the hunger period in northern Nigeria, therefore, pickers sell the commodity immediately to purchase much needed food.

Literature on the Shea industry stresses that the industry is dominated by women. Moreover, women are among the most vulnerable and the poorest in society. Majority of them that are engaged in the Shea industry for instance, do so because of the potential of the industry to reduce poverty levels among women in particular. It is argued that all artisanal Shea butter producers are women (Techno serve 2004). Financing the production and marketing of the Shea industry is therefore an important course for development. The Shea processing is dominated by women and therefore contributes to significant proportion of their income. Women are therefore, empowered economically through their engagement in the industry. Therefore, reliable evaluation of Shea nut processing to the socio-economic development of the rural populace is very important. 


\section{The study area}

\section{Materials And Methods}

The study was carried out in Ganye Local Government area, located in the Southeastern part of Adamawa State (Longitude $12^{0} \mathrm{~N}$, Latitude $09^{0} \mathrm{E}$ ) Figure 1. It is bounded by Jada to the North, Mayo-Belwa and Taraba State to the West, Toungo to the South and to the East Cameroon Republic (Adebayo, 1999). It has a land mass of $2291.42 \mathrm{~km}^{2}$ and a population of 164,087 (NPC, 2007). The mean annual temperature of the study area is $26.7^{\circ} \mathrm{C}$ and the mean annual rainfall ranges between $1000 \mathrm{~mm}$ and $1600 \mathrm{~mm}$ with a distinct dry season which begins in November, and ends April and the wet season begins in April and ends in October or sometimes in November. The area is located within the Guinea Savannah Zone of the Nigeria's vegetation Zones (Adebayo 1999). The major economic activity in the area is agriculture, food crops grown in the area includes Maize, sorghum, cowpea, Cassava and Potatoes. While Cash crops such as Ground nuts, Rice, Yam and Sugarcane are produced in large quantities. The famers are also engaged in collection and processing of non-timber forest such as Shea nuts. Major livestock reared in the Zones are cattle, sheep and goats (Ad seeds, 2004).

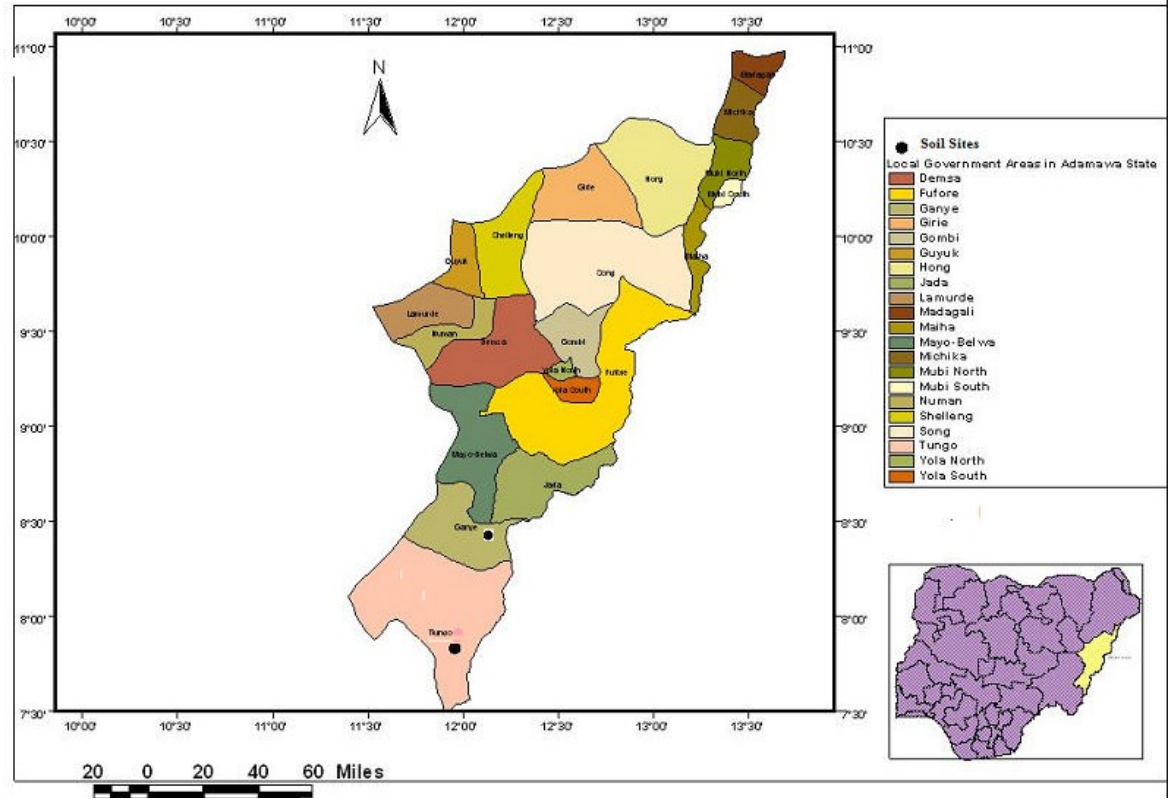

Figure 1: map of Adamawa State, Showing the Study Area

\section{Methods of data collection and analysis}

Data were collection from the communities involved in the use of non-timber forest products. A total of one hundred and fifty (150) respondents were sampled which translated to fifty (50) respondents per community. Main data in the questionnaires includes- relevant Socio-economic status of respondent's, Livelihoods activities, types of equipment use for Shea butter processing and market availability. The questionnaires completed were retrieved, coded and subjected to descriptive statistical analysis.

\section{Socio-economic Characteristics of the respondents}

\section{Results and Discussion}

The result in Table 1 indicates that $63.3 \%$ of the respondents are female and $36.7 \%$ are male. This shows that Shea butter enterprise in the study area is mostly dominated by female, even though $36.7 \%$ of the males are also involved in the enterprise. The possible reasons might be due to the nature and operations involved in the production processes and hence less participation of the men folks. Some researches (Awono et al., 2010 and Hossain, 2008) have reported a growing involvement of women in non timber forest products enterprise than men. They further maintained that this enterprise offer great opportunity for women, most especially in the informal economic in order to enhance the effectiveness of Shea butter enterprise in support of rural livelihood, greater involvement of women are essential particularly in high technology processing.

$63.3 \%$ of the respondents are within the age range of 30-40 years, representing the active part of the population engaged in Shea butter enterprise while, $26.7 \%$ are within the age range of 41-50 years (Table 1). A good number of the respondents (73.3\%) are married and $23.3 \%$ are still single (Table 1). This suggest that Shea butter enterprise in the study area is mostly associated with the married individuals and it is also likely that they engaged their family members in picking of Shea fruits and hence making the enterprise relatively simple in 
operation. In the aspect of education, $76.7 \%$ of the respondents had no formal education. Nevertheless, $6.7 \%$ and $16.7 \%$ of the respondents had primary and secondary education respectively. This indicates that Shea butter enterprise in this area is mostly dominated by the respondents who had no formal education but depends on their local skills in Shea butter processing. Nevertheless, Shea butter enterprise can be integrated within the on-going skill acquisition training in order to enhance the productivity capacity of the rural people. It will provide the possibilities for many existing rural enterprise to get involved not only in protecting Shea trees, but also planting, processing, packaging and marketing of Shea butter. According (Chigbu et al, (2012), this could lead to more direct employment generation, better economic empowerment and well being of the rural populace.

Steian (2003) pointed out that education is one of the important human capitals which play important roles in determining status in society. Education is expected not only to contribute to people's ability to read and understand instructions but also help them to adopt new techniques.

The lack of formal education among Shea butter processors may limit their ability to adopt modern processing techniques and marketing.

In the case of primary occupation of the respondents, $53 \%$ are Shea butter processors (Table 1), about $43 \%$ had farming/Shea butter processing as their primary of means of livelihood. Livelihoods Activities

Table 2 indicates that $53.3 \%$ of the respondents are not full time Shea butter processors, but on the other side $46.7 \%$ mentioned that Shea butter enterprise remains one of their major occupations in support of livelihood. Almost all the respondents $(100 \%)$ indicated that they are also engaged in other form of business in order to diversify their sources of income to enable them maintain livelihoods security.

Most of the respondents (76.7\%) mentioned that they were engaged in Shea butter enterprise for about 5-10 years, $13.3 \%$ for $11-15$ years and $10 \%$ for about 26 years and above (Table 2). This shows that even though majority of the respondents had no formal education, but in the process of constants use of the traditional methods in Shea butter processing, a high skill can be acquired in the enterprise.

\section{Sources and Methods of Shea Butter Processing}

Table 3 indicates that $66.7 \%$ of the respondents picked Shea fruits under Shea trees, $26.7 \%$ maintained that they both picked and buy more fruits from sellers and $6.7 \%$ indicated that they buy fruits from pickers. This finding corroborate with the study conducted by hall et al, (1996), that Shea nuts remained a picking products in Shea butter processing. The respondent's mentioned that the quantity of Shea fruits picked varies, $76.7 \%$ indicates that they normally picked quarter to 1 bag per day and $16.7 \%$ maintained that they usually picked $2-4$ bags per days. Only 3.35\% indicate that they picked 5-8 bags and more than 10 bags per day respectively (Table 3 ). This means that the quantity of Shea fruits picked per day is relatively small, this could either be due to scarcity of Shea trees (as a result of tree felling for other uses), or low productivity of the available species. The methods of processing employed by the respondents also varied. $73.3 \%$ of the respondents employed manual method of processing, $23.3 \%$ uses mechanize and 3.3\% semi-mechanize methods respectively (Table 3 ). This revealed that Shea butter processing is still low.

\section{Marketing and seasonality of Shea butter}

Marketing is the sum total of all business activities involved in the movement of commodities from production to consumption. It is the method of bringing the impersonal forces of demand and supply together irrespective of the location of the market (Adekanye, 1988). Arene (1998) defined market as an area or setting in which price making forces (demand and supply) operate. Marketing according to Nwokoye (2000) is the process of planning and executing the conception, pricing, promotion and distribution of ideas, goods and services to create exchange that satisfy individual and organisational objectives. It involves the provision of time, form, place and possession utilities of commodities. Reddy et al (2004) defined marketing as the economic process by which goods and services are exchanged between the producers and the consumers and their values determined in terms of money prices.

Shea butter marketing as explained by the respondents in the study area was based on: retailing, as mentioned by $43.3 \%$ of the respondents, $40 \%$ are involved in whole selling and $16.7 \%$ are both whole sellers and retailers (Table 3). $83.3 \%$ of the respondents maintained that the production of Shea butter is not all year round, $16.7 \%$ mentioned that they do maintain their production all year round. The findings of this study revealed that the processing of Shea butter is mostly a seasonal enterprise. This could either be due to scarcity of input (Shea nuts) or lack of technology that could enhance sustainable production. $60 \%$ of the respondents maintained that there is market availability for Shea butter in the study area. This means that Shea butter enterprise when encourage can be use as a means to support rural livelihoods.

At the same time $90 \%$ of the respondents maintained that availability and supply of Shea butter is mostly around May-August (Table 3). This shows that availability of raw materials (Shea nut) is mostly within this period. The lean period of Shea butter according to the respondents (50\%) was between January-April, this period is characterized by fall in supply of Shea butter and the price usually move up, $30.5 \%$ of the opinion that 
September- December remain the period that is marked with fall in supply of Shea butter. This indicates that the price of Shea butter is mostly high around January- April, which could either be due to high cost of input or high demand of the product.

\section{Challenges of Shea Butter Processors}

Most of the respondents (90\%) pointed out that they do not receive any kind of assistance from government or nongovernmental organization in order to enhance Shea butter processing enterprise (Table 5). $60 \%$ of the respondents explained that the major challenges mostly encountered in Shea butter enterprise is that of lack of processing equipment, others $(20 \%)$ said that they also face some technical and low inputs challenges. Majority of the respondents $(90 \%)$ are of the opinion that government should provide them with support and also training to enhance their productivity (Table 5). $10 \%$ of them added that processing equipment when provided can highly enhance their livelihoods (Table 5).

All the respondents maintained that Shea tree plays a vital role in support of their livelihoods (Table 2). This means that Shea trees in the study areas are important economic plants. $73.3 \%$ of the respondents revealed that in order to control the distribution of Shea in their communities, they hinder the cutting of Shea trees and also maintained public awareness concerning the importance of the tree. At the same time the respondents (76.7\%) mentioned that they do plant and protect Shea trees on their farms (Table 6). Moreover, the respondents (76.7\%) said there is law regarding protection of Shea trees in their community, while $23.3 \%$ pointed out that they do not have any idea concerning laws regarding the protection of Shea trees (Table 6). $80.0 \%$ of the respondents maintained that sanctioning is one of the penalties used on those who are involved in destruction of Shea trees within the community (Table 6).

\section{Conclusion}

\section{Conclusion and Recommendations}

Vitellaria paradoxa provide not only an important support for sustainable rural development but also a way for livelihood support and maintaining livelihood security for the rural people. Even through, they are not the main source of income and employment for rural people, they play significant role in the support of livelihood security of the rural poor. It was clear that livelihood diversification, food security, household asset accumulation, employment generation, financial savings are some of the opportunities rural producers and sellers gain from being livelihood in Shea butter enterprise. Nevertheless, a lot of challenges were identified to be working against these potential opportunities. These are mainly the lack of processing equipments capital, technical skills and government support

\section{Recommendations}

Provision of economic incentives and technical assistance will facilitate and boast the Shea enterprise in the study area.

Government should support the Shea butter enterprise through skill enhancement program. A deliberate policy should be maintained that will provide public awareness.

Farmers should be encouraged to protect and plant Shea trees on their farms.

Table 1: Socio-Economic Characteristics of the Respondents

\begin{tabular}{|c|c|c|}
\hline Sex & Frequency $\quad \mathrm{N}=150$ & Percentage \\
\hline Male & 55 & 36.7 \\
\hline Female & 95 & 63.3 \\
\hline Total & 150 & 100 \\
\hline \multicolumn{3}{|l|}{ Age (years) } \\
\hline $30-45$ & 95 & 63.3 \\
\hline $41-50$ & 40 & 26.7 \\
\hline $51-60$ & 5 & 3.3 \\
\hline $61-70$ & 10 & 6.7 \\
\hline Total & 150 & 100 \\
\hline \multicolumn{3}{|l|}{ Marital Status } \\
\hline Married & 110 & 73.2 \\
\hline Single & 35 & 23.3 \\
\hline Widows & 5 & 3.3 \\
\hline Total & 150 & 100 \\
\hline \multicolumn{3}{|l|}{ Educational Qualification } \\
\hline No Formal Education & 115 & 76.7 \\
\hline Primary Education & 10 & 6.7 \\
\hline Secondary Education & 25 & 16.7 \\
\hline Total & 150 & 100 \\
\hline \multicolumn{3}{|l|}{ Occupation } \\
\hline Shea butter Processing & 80 & 53.37 \\
\hline Farming/Shea butter Processing & 65 & 43.33 \\
\hline
\end{tabular}


Socio-Economic Contribution of Shea Tree (Vitellaria paradoxa) in Support of Rural Livelihood

\begin{tabular}{lll}
\hline Craftsmen & 5 & 3.33 \\
Total & $\mathbf{1 5 0}$ & $\mathbf{1 0 0}$ \\
\hline
\end{tabular}

Source: Field Survey (2012)

Table 2: Livelihoods Activities and Contribution of Shea trees

\begin{tabular}{|c|c|c|}
\hline Full time Shea butter processor & $\begin{array}{ll}\text { Frequency } & \mathrm{N}=\mathbf{1 5 0}\end{array}$ & Percentage \\
\hline Yes & 70 & 46.7 \\
\hline No & 80 & 53.3 \\
\hline Total & 150 & 100 \\
\hline \multicolumn{3}{|l|}{ Engaged in other Business } \\
\hline Yes & 150 & 100 \\
\hline No & 0 & 0 \\
\hline Total & 150 & 100 \\
\hline \multicolumn{3}{|l|}{ Years of Experience } \\
\hline $5-10$ & 115 & 76.7 \\
\hline $11-15$ & 20 & 13.3 \\
\hline 26 and above & 15 & 10.0 \\
\hline Total & 150 & 100 \\
\hline \multicolumn{3}{|l|}{ Contribution of Shea trees } \\
\hline Yes & 150 & 100 \\
\hline No & 0 & 0 \\
\hline Total & 150 & 100 \\
\hline
\end{tabular}

Source: Field Survey (2012)

Table 3: Sources and Methods of Shea Butter processing

\begin{tabular}{|c|c|c|}
\hline Source of Shea nuts & $\begin{array}{ll}\text { Frequency } & \mathrm{N}=150\end{array}$ & Percentage \\
\hline Picking of Shea fruits under trees & 100 & 66.7 \\
\hline Picking and Buying of more fruits & 40 & 26.7 \\
\hline Buying of fruits from Pickers & 10 & 6.7 \\
\hline Total & 150 & 100 \\
\hline \multicolumn{3}{|l|}{ Quantity of Shea fruits Picked/day } \\
\hline $1 / 4-1$ bag & 115 & 76.7 \\
\hline $2-4$ bags & 25 & 16.7 \\
\hline $5-8$ bags & 5 & 3.3 \\
\hline$>10$ bags & 5 & 3.3 \\
\hline Total & 150 & 100 \\
\hline \multicolumn{3}{|l|}{ Method of Shea butter processing } \\
\hline Manual & 110 & 73.3 \\
\hline Mechanize & 35 & 23.3 \\
\hline Semi-mechanize & 5 & 3.3 \\
\hline Total & 150 & 100 \\
\hline
\end{tabular}

Source: Field Survey (2012)

Table 4: Marketing and Seasonality of Shea butter

\begin{tabular}{|c|c|c|c|}
\hline Marketing method & Frequency & $\mathrm{N}=150$ & Percentage \\
\hline Whole sales & 60 & & 40.0 \\
\hline Retailing & 65 & & 43.3 \\
\hline Whole/Retailing & 25 & & 16.7 \\
\hline Total & 150 & & 100 \\
\hline \multicolumn{4}{|c|}{ Seasonality of Shea Processing } \\
\hline Yes & 25 & & 16.7 \\
\hline No & 125 & & 83.3 \\
\hline Total & 150 & & 100 \\
\hline \multicolumn{4}{|c|}{ Shea butter Availability } \\
\hline January-April & 5 & & 3.3 \\
\hline May-August & 135 & & 90.0 \\
\hline September-December & 10 & & 6.7 \\
\hline Total & 150 & & 100 \\
\hline \multicolumn{4}{|c|}{ Fall in Shea butter supply } \\
\hline January-April & 75 & & 50.0 \\
\hline May-August & 30 & & 20.0 \\
\hline September-December & 45 & & 30.0 \\
\hline Total & 150 & & 100 \\
\hline \multicolumn{4}{|l|}{ Market availability } \\
\hline Yes & 90 & & 60.0 \\
\hline No & 60 & & 40.0 \\
\hline Total & 150 & & 100 \\
\hline
\end{tabular}

Source: Field Survey (2012) 
Table 5: Challenges and Government Support in Shea butter Processing

\begin{tabular}{|c|c|c|}
\hline Challenges face & Frequency $\quad \mathrm{N}=150$ & Percentage \\
\hline Technical/Inputs & 30 & 20.0 \\
\hline Equipment & 90 & 60.0 \\
\hline Capital & 30 & 20.0 \\
\hline Total & 150 & 100 \\
\hline \multicolumn{3}{|l|}{ Government Assistance } \\
\hline Yes & 15 & 10.0 \\
\hline No & 135 & 90.0 \\
\hline Total & 150 & 100 \\
\hline \multicolumn{3}{|l|}{ Solutions to Challenges } \\
\hline Govt. Support and Awareness & 135 & 90.0 \\
\hline Provision of equipment/Training & 15 & 10.0 \\
\hline Total & 150 & 100 \\
\hline
\end{tabular}

Source: Field Survey (2012)

Table 6: Protection and Laws regarding destruction of Shea trees

\begin{tabular}{|c|c|c|c|}
\hline Method of control & Frequency & $\mathrm{N}=150$ & Percentage \\
\hline Control of cutting/farmers education & 110 & & 73.3 \\
\hline Enlightenment on uses of Shea trees & 40 & & 26.7 \\
\hline Total & 150 & & 100 \\
\hline \multicolumn{4}{|l|}{ Planting/Protecting of Shea trees } \\
\hline Yes & 115 & & 76.7 \\
\hline No & 35 & & 23.3 \\
\hline Total & 150 & & 100 \\
\hline \multicolumn{4}{|l|}{ Laws on Protection of Shea trees } \\
\hline Yes & 115 & & 76.7 \\
\hline No & 35 & & 23.3 \\
\hline Total & 150 & & 100 \\
\hline \multicolumn{4}{|l|}{ Nature of the laws/Penalty } \\
\hline Warning & 30 & & 20.0 \\
\hline Sanctioning & 120 & & 80.0 \\
\hline Total & 150 & & 100 \\
\hline
\end{tabular}

Source: Field Survey (2012)

\section{References}

[1]. Adamawa State Economic Development Strategy, ADSEED (2004)

[2]. Adamawa State Planning Commission October, 2004 ABTI press

[3]. Addaquay, J. 2004. The Shea butter Value Chain, Refining in West Africa WATH Technical Report No 3, Dakar, WATH

[4]. Adebayo, AA(1999) Climate I \&ii (Sun Shine, Temperature, Evaporation and relative humidity): in Adebayo, AA and Tukur, A E (ads) Adamawa in Maps, parakeet publishers Yola. Nigeria. PP 15-30

[5]. Adekanye, T.O. (1988). The markets of foodstuffs in western Nigeria. In Adekanye, T.O. (eds); Readings in Agricultural Marketing Longman, Ibadan. Pp $12-22$.

[6]. Agbanelo, D U(2006). Promotion of Standardization in Africa for Collective Good contribution to Regional International Expert Consultation on Establishment and Harmonization of Africa Regional standards for Shea butter and Shea kernel, Accra, ARSO

[7]. Arene, C.J. (1988). Introduction to Agricultural Marketing Analysis for Developing Economic. Fulladu Publishing Company Nsukka, Nigeria. Pp 1-23.

[8]. Aryeetey, E (1996). Rural Finance in Africa: "Institutional Development Access for Poor". Annual world Bank Conference on Development Economics Report, World Bank/IBRD, PP: 149- 173.Carette C Malotaux M Leeuwen M \& Tolkamp M (20090, Shea nut and butter in Ghana: Opportunities And constraints for local processing. Wageninggen University, the Netherlands, and The Residence foundation.

[9]. Hall, J.B, D.P Aebischer, H.F Tomlinson, Eosei - Amaining and J.R hindle, (1996). Vittellaria paradoxa: A monorgraph. School of Agricultural forest Science publication number: 8, Bangor, University of Wolves.

[10]. Holtzman, J (2004). The Shea butter value chain: Study synthesis and Recommendation for WATH. WATH Technical report No. 1, Dakar WATH

[11]. Kletter, L (2002). Highlights for 2002 planning. Accra Techno serve Ghana.

[12]. Lovett,P(2004). The Shea butter value chain: production, transfoemation and marketing in West Africa. WATH Technical report No.2 Dakar, WATH.

[13]. Lovett, P N and Haq. N. (2000). Diversity of Shea butter nut tree (Vetilaria Paradoxa Gaertn C.F) in Volume 94 Lagos, Nigeria.

[14]. Nwokoye, N. (2000). Modern Marketing for Nigeria Principles and Practice Second edition, Africa Publishers Limited, Nigeria. Pp $34-46$

[15]. Prudence, A. (2006). Ghana Standards DS 288:2006, Specifications for unrefined Shea butter, Accra, Ghana Standard Board.

[16]. Reddy, Subba S., Ram Raghu, P., Sastry Neelakanta T.V. and Devi Bhavani, I. (2004). Agricultural Economics. Oxford \& IBH Publishing Co. PVT. Ltd New Delhi.

[17]. Stathacos C. (2004). The Shea butter value chain: The US market study. Technical report No. 4 Dakar, WATH.

[18]. Techno serve-Ghana. 2004. The industry strategic plan, Accra.Wallace - Bruce, Y. (1995). Do it herself: Women and technical innovation. Shea butter extraction in Ghana. H. Apliton (ed), London, intermediate technology publications.

\section{Acknowledgements}

The authors would like to thank all the respondents who availed us their time during field data collection for this study. 